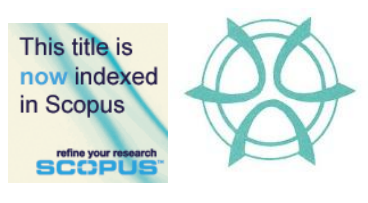

PLANNING MALAYSIA:

Urban Planning and Local Governance

Volume III (2014), Page 27- 46

\title{
E-PAYMENT AT THE LOCAL GOVERNMENT LEVEL: A STUDY OF MAJLIS BANDARAYA SHAH ALAM AND MAJLIS DAERAH KAMPAR
}

\author{
Rustam Khairi Zahari ${ }^{1}$, Raja Noriza Raja Ariffin ${ }^{2}$, Nurhawani Zamin ${ }^{3}$ \\ and Norzailawati binti Mohd Noor ${ }^{4}$ \\ ${ }^{1 \& 4}$ Kulliyyah of Architecture and Environmental Design \\ INTERNATIONAL ISLAMIC UNIVERSITY MALAYSIA \\ ${ }^{2}$ Faculty of Economic and Administration \\ UNIVERSITY OF MALAYA \\ Economic Planning Unit \\ PRIME MINISTER'S DEPARTMENT
}

\begin{abstract}
Information and Communication Technology (ICT) adoption through the implementation of electronic government (e-Government) helps improves local authority's service delivery for the benefit of the community. Many of the local authorities have adopted the online payment method for the assessment rate collection. Despite the notion that e-Government increased productivity and improved efficiency, citizen's usage is still considered minimal and has been comparatively low especially in services involving transactional. This study investigates the factors influencing the usage of online payment method in local authority's assessment rate collection. Data for this study was collected through questionnaire, interview and document analysis. The findings showed that perceived usefulness, perceived ease of use, perceived risk, payment receipt issuance and income level seem to influence user's intention to adopt the online payment method.
\end{abstract}

Keyword: Urban morphology, GIS, Remote sensing, urban planning, urban governance

\footnotetext{
${ }^{1}$ Assistant Professor at the Department of Urban and Regional Planning. Email: rustam@iium.edu.my

${ }^{2}$ Senior Lecturer at the Department of Administrative Studies and Politics. Email: rnoriza@um.edu.my

3 Principal Assistant Director at the Economic Planning Unit. Email: nurhawani.zamin@epu.gov.my

${ }^{4}$ Assistant Professor at the Department of Urban and Regional Planning. Email: norzailawati@gmail.com
} 
Rustam Khairi Zahari, Raja Noriza Raja Ariffin, Nurhawani Zamin and Norzailawati binti Mohd Noor E-Payment at the Local Government Level: A Study of Majlis Bandaraya Shah Alam and Majlis Daerah Kampar

\section{INTRODUCTION}

The advent of the ICT has revolutionized the way government works. The electronic government or the e-Government has shifted and transform the way government operates. According to the United Nations (2003), two interrelated phenomena contributed to the engagement of e-Government in the public service. First, the rapid globalization that opens up a more competitive products and services among nation. Second, the advancement of the ICT that offers new approaches in the betterment and improvement of service delivery that includes those provided by the local authorities to the communities under their purview. The e-Government today is seen not only as a vehicle to enhance public service delivery, but has increasingly shifted towards a public-centered development (United Nations, 2012). According to the latest report of the United Nations e-Government Survey 2012, the ICT and e-Government is dubbed as an important tool towards achieving a sustainable development for all (United Nations, 2012). The increasing number of e-Government implementation is evident throughout the world not only for public service delivery but also as a mean of interaction between government and citizens (Akman, Yacizi, Mishra, \& Arifoglu, 2005; Gupta \& Jana, 2003; Ndou, 2004; Ramlah, Nor Shahriza, Norshidah, \& Abdul Rahman, 2007).

According to Tayib (2000), the application of ICT has been identified as an important factor that contributes towards an effective revenue collection system in the United Kingdom and the United States (as cited in Yurita Yakimin, Marlina and Mohamad Sharofi, 2005). In Malaysia, the government has put strong emphasis on the application of ICT in public service delivery. In 1997, following the launch of Multimedia Super Corridor (MSC), the government introduced the e-Government as a flagship application under the MSC with the objective to reinvent the government through connectivity and to spearhead the country into the Information Age (Malaysian Administrative Modernisation and Management Planning Unit [MAMPU], Prime Minister's Department, 1997). One of the e-Government key projects includes the electronic services (e-Services), aim to enable citizens to have 24-hours access through a one-stop service window such as online payment for utility bills.

In the Ninth Malaysia Plan, the government encouraged the local authorities to adopt the online payment system as one way to strengthen their revenue collection (Economic Planning Unit, Prime Minister's Department, 2006). With the e-Government initiative already in place, the assumption is that the assessment rate collection and payment should have 
been a lot easier and convenient to both local authorities and rate payers alike. The aim of this paper is to investigate the factors that influence the usage of online payment method in local authority's assessment rate collection; with specific reference to two local authorities, Majlis Bandaraya Shah Alam (MBSA) in Shah Alam, Selangor and Majlis Daerah Kampar (MDKpr) in Kampar, Perak.

\section{LITERATURE REVIEW}

Local authority is the level of government that deals with the people the most and entrusted to administer local affairs with devolved powers (Ainul Jaria Maidin and Bashiran Begum Mobarak Ali, 2009). In dealing with the people on administrative matters and with the burgeoning of online interactions, it is only logical that these transactions should take advantage of the availability of the electronics communication (Norhaslina Hassan et. al., 2013). Studies conducted on the practice of e-Government in Malaysia found that in general citizen's usage is comparatively low (Maizatul Haizan, Mohammed Zin, Ali, Wan Idros \& Mohd. Yusof, 2011; Siddique, 2008, United Nations, 2005). Among the factors that are established to be significant towards citizen's intention to use e-Government are trust, perceived usefulness, perceived relative advantage, perceived image, perceived ease of use and trust of the government (Ooh, Suhaiza, Ramayah \& Fernando, 2009; Ramlah, Norshidah, Abd Rahman \& Murni, 2011).

According to the United Nations' e-Government Survey, Malaysia's overall performance has not been encouraging and has been listed within the range of 30 to 45 in the survey ranking since 2003. In contrasts, the Republic of Korea has managed to position itself in the first rank in 2010 and 2012. Interestingly, the Republic of Korea was ranked $15^{\text {th }}$ when the survey was first initiated in 2003, and has since shown extraordinary improvement. Its achievement is attributed to the government's ICT policy as outlined by the Ministry of Public Administration and Security (MOPAS) (Sung-mi, 2012). The Republic of Korea government has an ICT road map in place with the launch of the Smart e-Government Plan together with the Mid-Long Term Mobile eGovernment Plan in 2011 to prepare themselves with the smart era of the information age. Earlier in 2010, the government of Republic of Korea passed the Personal Information Protection Law in its effort to protect personal data online. These are among the initiatives targeted by the Republic of Korea to achieve a world class e-Government via four strategic points (Sung-mi, 2012). First, the development of a targeted 917 mobile e- 
Rustam Khairi Zahari, Raja Noriza Raja Ariffin, Nurhawani Zamin and Norzailawati binti Mohd Noor E-Payment at the Local Government Level: A Study of Majlis Bandaraya Shah Alam and Majlis Daerah Kampar

Government services by 2015. Second, the establishment of a safe online environment through the protection of personal data information. Third, strengthening the peoples' support to realize an information-based society. Fourth, pushing for mutual growth information for the benefit of the public and private sector.

Earlier studies have identified factors that influenced the implementation of e-Government. The basic foundation of the implementation should be citizen focused in order to establish connectivity between the government and citizens (Bertot \& Jaeger, 2006; Evans \& Yen, 2006; Reddick \& Turner, 2012; Shareef, Kumar, Kumar, \& Dwivedi, 2011). Engagement with the citizens is done through the dispersion of technology, in most cases, the internet. Sandolval-Almazan and Gil-Garcia (2012) further assert that although e-Government diffusion is essential, citizen adoption is far more important to embrace the service. The standpoint is echoed by Helbig, Gil-Garcia and Ferro (2009) who found that many eGovernment services has neither produced the intended results of a more efficient government nor an engaged participation by the citizens. Equally as important in the implementation of the e-Government is the usability. Venkatesh, Chan and Thong (2012) identify usability as one of the four key characteristics of transactional e-Government services. Based on the findings, the study recommended the need to recognize the preferences of various segment of users before executing the e-Government initiative. Another imperative factor that influences the implementation of eGovernment is privacy and security. Now that the services are done electronically rather than manually, people feel more insecure with regards to their personal data and information especially involving financial transactions. As Yu, Hsi and Kuo (2002) pointed out; security becomes the main concern when people deal with online transaction because of the absence of direct contact between the sender and the receiver. $\mathrm{He}$ and Mykytyn (2007) stress that privacy and security issues might deter people from using online services especially online payment fearing that their account may be misused.

Four most relevant and numerously cited theories have been identified to present the ideas of previous research. The Diffusion of Innovation (DOI) theory is commonly used in research related to information system to determine user's acceptance towards new technologies. The DOI theory proposed that the rate of diffusion is influenced by five important characteristics of innovation: (1) relative advantage, (2) complexity, (3) compatibility, (4) trialability, and (5) observability (Lai \& Rieck, 2005; Ooh et al., 2009; Ramlah et al., 2011; 
Rogers, 2003). Ooh et al. (2009) observe that if the potential user experienced one of these factors to be inconsistent, the user is least likely to embrace the benefit of innovation. Although the DOI theory is widely used in studies related to e-Government, Shareef et al. (2011) argue that the theory is unable to capture the crux of citizen's behavior in adopting eGovernment.

The Technology Acceptance Model (TAM) is widely used to study user's acceptance of technology (Carter \& Belanger, 2005; He \& Mykytyn, 2007; Maniam \& Halimah, 2008; Ooh et al., 2009: Shyu \& Huang, 2011). Similar to the DOI theory, TAM suggested that users who find it useful are more willing to adopt the technology. TAM featured two determinants that affect user's acceptance of technology: (1) perceived usefulness; and (2) perceived ease of use (Davis, 1989). The perceived ease of use refers to the free effort involved in applying the technology. The TAM attempted to investigate what drives user behavior, despite the cynicism that it can be a difficult task.

The Theory of Planned Behavior (TPB) suggested three variables that determine the intention and actual behavior of a person: (1) attitude, (2) subjective norms, and (3) perceived behavioral control (Ajzen, 1991). Hung, Chang and Yu (2006) had used the TPB as a model in their study on determinants of user acceptance of the e-Government services and found that subjective norms and perceived behavioral control are significant with adopters' intention not to use and to use technology, respectively. According to Maizatul et al. (2011), the Unified Theory of Acceptance and Use of Technology (UTAUT) is the latest and powerful theory to understand users' acceptance of Information System. Venkatesh, Morris, Davis and Davis (2003) claim that the UTAUT was able to explain 70 per cent of technology acceptance behavior, as compared to other models which normally explain only about 40 per cent of acceptance.

The review of literature above has demonstrated the various manners that people have adopted when dealing with the authority electronically and it is evidenced that more may need to be done to ensure that the public are comfortable and felt secured in these transactions. With the expanded network and the availability of smart devices, it is anticipated that more studies will be conducted on this subject matter especially at the local government level. 
Rustam Khairi Zahari, Raja Noriza Raja Ariffin, Nurhawani Zamin and Norzailawati binti Mohd Noor E-Payment at the Local Government Level: A Study of Majlis Bandaraya Shah Alam and Majlis Daerah Kampar

\section{RESEARCH METHODOLOGY}

This paper employs the interview method and administered questionnaire. The purpose of the interview with the officer in charge is to gather information about the implementation of the online payment method at MBSA and MDKpr. Subsequently, follow up on the data regarding the assessment rate collection is made through e-mail. The respondents for the questionnaire comprise of residents in the administration area of MBSA and MDKpr. Using the area sampling, areas in MBSA and MDKpr are clustered accordingly and questionnaires are distributed according to the clustered area to meet the most representation of the population. A total of 300 questionnaires were distributed in the MDKpr locality and another 300 in the MBSA locality. The entire questionnaire is composed of closed questions except for the last question which is open-ended. This is to allow respondents to freely comment on any issue related to the online payment method.

Of the 300 distributed questionnaires in the MDKpr locality, only 46 were returned, a response rate of 15 per cent. Three of the returned questionnaires have to be excluded because of incomplete answers. In the MBSA locality, 66 out of 300 questionnaires were returned, giving a response rate of 22 per cent. However, seven of them are not usable because of too many incomplete answers. The low response rate is likely to be caused by residents who are tenants and does not own the house. Tenants normally do not pay the assessment rate as the cost is borne by the house owners. The best of effort has been put to identify houses that indicate the resident as owner of the house.

\section{RESULTS}

The value of Cronbach's alpha for all four constructs exceed 0.7, a range that is deemed acceptable and reliable. Table 1 show that a majority of the respondent (35.3 per cent) is in the range of $41-50$ years of age. A majority have a monthly income level of RM5, 000 and above (38.0 per cent). The survey shows that 82.4 per cent of respondents use the internet with 94.0 per cent of them has internet access at home. Among the internet users, they frequent the internet daily (69.0 per cent), suggesting a very active use of the internet among users. 
PLANNING MALAYSIA

Urban Planning and Local Governance

Table 1: Demographic profile.

\begin{tabular}{|c|c|c|c|c|c|}
\hline Variable & Frequency & $\begin{array}{l}\text { Per } \\
\text { cent }\end{array}$ & Variable & Frequency & Per cent \\
\hline Gender & & & Internet & & \\
\hline Male & 69 & 67.6 & Usage & & \\
\hline Female & 33 & 32.4 & $\begin{array}{l}\text { Yes } \\
\text { No }\end{array}$ & $\begin{array}{l}84 \\
18\end{array}$ & $\begin{array}{l}82.4 \\
17.6\end{array}$ \\
\hline \multicolumn{6}{|l|}{ Age } \\
\hline Below 20 & 1 & 1.0 & Internet & & \\
\hline $20-30$ & 3 & 2.9 & Use & & \\
\hline $31-40$ & 25 & 24.5 & Experience & & \\
\hline $41-50$ & 36 & 35.3 & Everyday & 58 & 69.0 \\
\hline $51-60$ & 25 & 24.5 & A few & 11 & 13.1 \\
\hline \multirow[t]{2}{*}{ Over 60} & 12 & 11.8 & times a & 4 & 4.8 \\
\hline & & & $\begin{array}{l}\text { week } \\
\text { A couple }\end{array}$ & 11 & 13.1 \\
\hline (Monthly) & 2 & 2.0 & of times a & & \\
\hline Below RM500 & 1 & 1.0 & month & & \\
\hline RM500 - RM1,000 & 19 & 19.0 & Rarely & & \\
\hline RM1,001 - RM2,000 & 15 & 15.0 & & & \\
\hline RM2,001 - RM3,000 & 15 & 15.0 & & & \\
\hline RM3,001 - RM4,000 & 10 & 10.0 & Internet & & \\
\hline RM4,001 - RM5,000 & 38 & 38.0 & access at & & \\
\hline \multirow[t]{3}{*}{ Over RM5,000 } & & & home & 79 & 94.0 \\
\hline & & & Yes & 5 & 6.0 \\
\hline & & & No & & \\
\hline
\end{tabular}

Additionally, the survey found that 42.4 per cent of respondents in MBSA preferred the online payment method. MBSA compared to MDKpr, offers a wider range of online payment method through eight banks: (1) Citibank, (2) Public Bank, (3) HSBC, (4) RHB Bank, (5) CIMB Bank, (6) Maybank, (7) MBF, and (8) UOB Bank. Figure 1 shows the assessment rate collection according to online banking preference. The majority of users preferred using online payment by Maybank followed by MBF and Citibank. It is assumed that the wider range of online banking offered by MBSA gives a broader choice for users to adopt the online payment method since it is more flexible for those having different bank accounts to make the payment online. 
Rustam Khairi Zahari, Raja Noriza Raja Ariffin, Nurhawani Zamin and Norzailawati binti Mohd Noor E-Payment at the Local Government Level: A Study of Majlis Bandaraya Shah Alam and Majlis Daerah Kampar

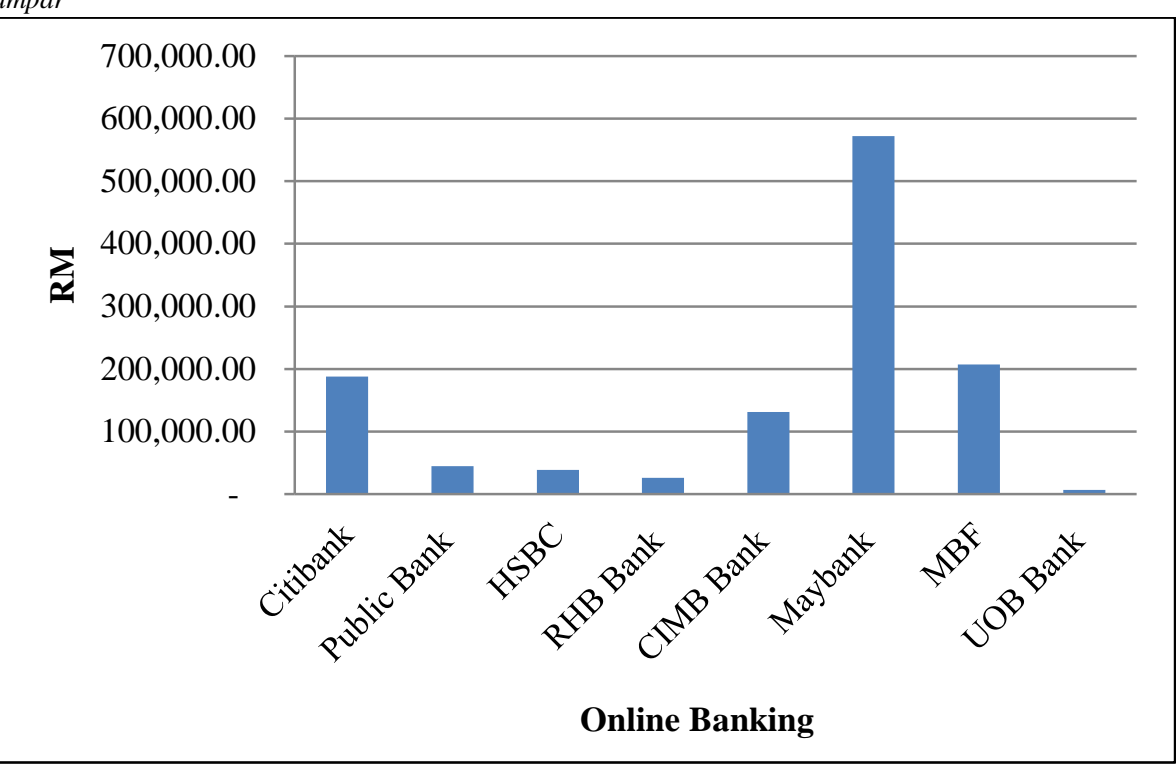

Figure 1: Assessment rate collection from online banking for MBSA (2011) Source: MBSA

An independent-sample t-test was conducted to compare male and female perception whether online payment saves time. Result in Table 2 shows that there was no significance difference between males and females in terms of their perception whether online payment saves time.

Table 2: Results of independent T-test on whether online payment saves time

\begin{tabular}{cccccccc}
\hline & \multicolumn{2}{c}{ Male } & \multicolumn{2}{c}{ Female } & & & \\
& Mean & SD & Mean & SD & df & t & $\begin{array}{c}\text { Sig. } \\
\text { (2-tailed) }\end{array}$ \\
\hline $\begin{array}{c}\text { Online } \\
\text { payment } \\
\text { saves } \\
\text { time }\end{array}$ & 2.75 & .557 & 2.50 & .718 & 49.195 & 1.738 & .088 \\
\hline
\end{tabular}


PLANNING MALAYSIA

Urban Planning and Local Governance

The five main independent variables employed in this study as the determinants of online payment method adoption are perceived usefulness, perceived ease of use, perceived risk, receipt issuance and income level. The dependent variable is the user's adoption on the online payment method. Pearson product-moment correlation coefficient is used to investigate the relationship among the group of variables. All five independent variables are found to be significantly correlated with the dependent variable. Results are shown in Table 3.

Table 3: Correlation analysis between online payment method usage factors

\begin{tabular}{lcccccc}
\hline Items & $\begin{array}{c}\text { Perceived } \\
\text { usefulness }\end{array}$ & $\begin{array}{l}\text { Perceived } \\
\text { ease of use }\end{array}$ & $\begin{array}{l}\text { Perceived } \\
\text { risk }\end{array}$ & $\begin{array}{l}\text { Receipt } \\
\text { issuance }\end{array}$ & $\begin{array}{l}\text { Income } \\
\text { Level }\end{array}$ & $\begin{array}{l}\text { User's } \\
\text { adoption }\end{array}$ \\
\hline $\begin{array}{l}\text { Perceived } \\
\text { usefulness }\end{array}$ & 1 & & & & \\
$\begin{array}{l}\text { Perceived } \\
\text { ease of use }\end{array}$ & $.675^{* *}$ & 1 & & & \\
$\begin{array}{l}\text { Perceived } \\
\text { risk }\end{array}$ & $-.437^{* *}$ & $-.396^{* *}$ & 1 & & \\
$\begin{array}{l}\text { Receipt } \\
\text { issuance }\end{array}$ & $-.419^{* *}$ & $-.427^{* *}$ & $.604^{* *}$ & 1 & \\
$\begin{array}{l}\text { Income } \\
\text { level }\end{array}$ & $.345^{* *}$ & $.292^{* *}$ & $-.300^{* *}$ & $-.464 * *$ & 1 & \\
$\begin{array}{l}\text { User's } \\
\text { adoption }\end{array}$ & $.556^{* *}$ & $.440^{* *}$ & $-.551 * *$ & $-.659 * *$ & $.435^{* *}$ & 1 \\
\hline
\end{tabular}

**Correlation is significant at the 0.01 level (2-tailed)

Among all the independent variables, perceived usefulness has the strongest, positive correlation with the dependent variable which is the online payment adoption, $r=.556, p<0.01$, two-tailed. This is followed by perceived ease of use, with a moderate, positive correlation with the dependent variable, $r=.440, p<0.01$, two-tailed. Perceived risk has a strong, negative correlation with user's adoption of the online payment, $r=-$ $.551, p<0.01$, two-tailed, with higher levels of perceived risk associated with lower levels of user's adoption. Receipt issuance has the strongest, negative correlation with the dependent variable, $r=-.659, p<0.01$, twotailed, with higher levels of receipt issuance associated with lower levels of user's online payment method adoption. Income level has a moderate, 
Rustam Khairi Zahari, Raja Noriza Raja Ariffin, Nurhawani Zamin and Norzailawati binti Mohd Noor E-Payment at the Local Government Level: A Study of Majlis Bandaraya Shah Alam and Majlis Daerah Kampar

positive correlation with user's intention to adopt online payment method, $r$ $=.435, p<0.01$, two-tailed.

\section{Hypotheses testing}

Each hypothesis was tested for statistical significance using Pearson correlation method. The results are as follows:

\section{Hypothesis One - Perceived Usefulness}

$\mathrm{H}_{1}$ : $\quad$ Perceived usefulness will positively influence the intention to adopt online payment method.

The results of Pearson correlation found that there was a strong, positive correlation between perceived usefulness and online payment adoption, $r=$ $.556, p<0.01$, two-tailed. Perceived usefulness was associated with user's intention to adopt the online payment method. Thus, hypothesis $\mathrm{H}_{1}$ is supported in the study. This result attests the findings of some previous studies. Ramlah et al. (2011) discover that perceived usefulness is a strong determinant for e-government adoption and is particularly valid in the government to citizen (G2C) adoption. Liao and Cheung (2002) find that individuals expect accuracy, speed and user friendliness as among the most important quality in the perceived usefulness of internet based e-Banking. Ooh et al. (2009) establish that perceived usefulness has a significant positive relationship with the adoption of e-Government services.

\section{Hypothesis Two-Perceived Ease of Use}

$\mathrm{H}_{2}$ : Perceived ease of use will positively influence the intention to adopt online payment method.

The results of Pearson correlation found that there was a moderate, positive correlation between perceived ease of use and user's online payment adoption, $r=.440, p<0.01$, two-tailed. Perceived ease of use was associated with user's intention to adopt the online payment method. Thus, hypothesis $\mathrm{H}_{2}$ is supported in the study. The result supports the findings of Poon (2008) who established that convenience and accessibility have positive effect on consumer adoption of e-Banking. The result is also consistent with the study by Ramlah et al. (2011) who found that perceived 
ease of use is a strong determinant for adoption of online tax filing or eFiling in Malaysia. According to the study, users are inclined to fill in the online tax filing at the leisure of their home rather than queuing up at the service counter. In a similar vein, Carter and Belanger (2005) and Ooh et al. (2009) propose that perceived ease of use is among the important predictors of user's intention to adopt e-Government services. These findings affirm Davis' (1989) TAM in which the model proposed that a technology is of no use if it is not easy to use.

\section{Hypothesis Three - Perceived Risk}

$\mathrm{H}_{3}$ : $\quad$ Perceived risk will negatively influence the intention to adopt online payment method.

The results of Pearson correlation found that there was a strong, negative correlation between perceived risk and user's online payment method adoption, $r=-.551, p<0.01$, two-tailed. Higher levels of perceived risk are associated with lower levels of user's online payment method adoption. Thus, hypothesis $\mathrm{H}_{3}$ is supported in the study. The result of Hypothesis Three is consistent with Pavlou (2003) who suggested that perceived risk is negatively related to user's intention. Belanger and Carter (2008), Hung et al. (2006) and Maizatul et al. (2011) also opined a significant correlation between perceived risk and user's intention to use.

\section{Hypothesis Four - Receipt Issuance}

$\mathrm{H}_{4}$ : Payment receipt issuance will positively influence the intention to use online payment method.

It is hypothesized that if a receipt is issued as a proof of payment, user is more likely to use the online payment method to pay the assessment rate. No known study has used this as a construct to determine user's intention to use e-Government and the like. However, based on similar studies by Eastin (2002) and Ramlah et al. (2011), receipt issuance becomes the independent variable in Hypothesis Four. The results of Pearson correlation found that there was a strong, negative correlation between payment receipt issuance and user's online payment method adoption, $r=-.659, p<0.01$, two-tailed. The results suggest that when receipt is issued upon payment via counter, users are not keen to adopt the online payment method for they are more 
Rustam Khairi Zahari, Raja Noriza Raja Ariffin, Nurhawani Zamin and Norzailawati binti Mohd Noor E-Payment at the Local Government Level: A Study of Majlis Bandaraya Shah Alam and Majlis Daerah Kampar

comfortable having a receipt as a proof of payment. Thus, hypothesis $\mathrm{H}_{4}$ is supported in the study. For the record, the negative correlation is due to the fact that at present the receipt is only issued when payment is made via the counter, hence there are users who opted not to use the online payment method because of the need to obtain the receipt.

\section{Hypothesis Five - Income Level}

$\mathrm{H}_{5}$ : User's income level will positively influence the intention to use online payment method.

Hypothesis Five seeks to investigate whether user's income level positively influence the intention to use online payment method. Hypothetically, users with higher income will have greater access to online facilities such as the internet and computer at home, hence enabling them to use the online payment method. The results of Pearson correlation found that there was a moderate, positive correlation between income level and user's online payment adoption, $r=.435, p<0.01$, two- tailed. User's income level was associated with user's intention to adopt the online payment method. Thus, hypothesis $\mathrm{H}_{5}$ is supported in the study. According to Akhter (2003), income is strongly related with opportunity cost of time in which as income increases, the perception of the value of time changes. Akhter (2003) hypothesizes that wealthier people are more likely to use the internet for online transaction. Based on Akhter's (2003) study, He and Mykytyn (2007) adopted the income level as one of the predictors to determine customer's intention to adopt the online payment method. While Akhter's (2003) study found that wealthier people are more likely to make online purchase, a similar study by $\mathrm{He}$ and Mykytyn (2007) advocate that income level does not influence customer's intention to pay bills online. A summary of the five hypotheses discussed above is presented in Table 4 . 
PLANNING MALAYSIA

Urban Planning and Local Governance

Table 4: Hypothesis accepted/rejected summary

\begin{tabular}{|c|c|}
\hline Hypothesis & Accepted/rejected \\
\hline $\begin{array}{l}\mathrm{H}_{1} \text { : Perceived usefulness will positively influence the intention to } \\
\text { adopt online payment method. }\end{array}$ & Accepted \\
\hline $\begin{array}{l}\mathrm{H}_{2} \text { : Perceived ease of use will positively influence the intention } \\
\text { to adopt online payment method. }\end{array}$ & Accepted \\
\hline $\begin{array}{l}\mathrm{H}_{3} \text { : Perceived risk will negatively influence the intention to adopt } \\
\text { online payment method. }\end{array}$ & Accepted \\
\hline $\begin{array}{l}\mathrm{H}_{4} \text { : Payment receipt issuance will positively influence the } \\
\text { intention to use online payment method. }\end{array}$ & Accepted \\
\hline $\begin{array}{l}\mathrm{H}_{5} \text { : User's income level will positively influence the intention to } \\
\text { use online payment method. }\end{array}$ & Accepted \\
\hline
\end{tabular}

A further analysis of multiple regression was carried out to analyze how well a set of variables is able to predict a particular outcome. As shown in Table 5, the selected predictors were accounted for 55.2 per cent of the variance of online payment adoption with $F=17.276$ significant at $p<0.05$. The results showed that two predictors were found significant; receipt issuance has the strongest impact on user's online payment method adoption $(b=-.402)$ followed by perceived usefulness $(b=.302)$. The findings implied that users are very much concern with the proof of payment when making assessment rate payment online. Users are also influenced to adopt the online payment method because of its usefulness, in this case it is deemed as cost and time saving for them. The finding is normal for an analysis of multiple regressions because a significant predictor independent variable in a simple linear regression may be significant in multiple regressions due to overlap of variance with other independent variables in the model. 
Rustam Khairi Zahari, Raja Noriza Raja Ariffin, Nurhawani Zamin and Norzailawati binti Mohd Noor E-Payment at the Local Government Level: A Study of Majlis Bandaraya Shah Alam and Majlis Daerah Kampar

Table 5: Influence of independent variables on online payment method

\begin{tabular}{|c|c|c|c|c|c|}
\hline & \multicolumn{2}{|c|}{ Unstandardized Coefficient } & \multicolumn{2}{|c|}{$\begin{array}{c}\text { Standardized } \\
\text { Coefficient }\end{array}$} & \multirow[b]{2}{*}{ Sig. } \\
\hline & B & Std. Error & Beta & $\mathbf{t}$ & \\
\hline $\begin{array}{l}\text { Perceived } \\
\text { usefulness }\end{array}$ & .080 & .030 & .302 & 2.662 & .010 \\
\hline $\begin{array}{l}\text { Perceived } \\
\text { ease of } \\
\text { use }\end{array}$ & -.010 & .039 & -.028 & -.255 & .799 \\
\hline $\begin{array}{l}\text { Perceived } \\
\text { risk }\end{array}$ & -.019 & .013 & -.156 & -1.501 & .138 \\
\hline $\begin{array}{l}\text { Receipt } \\
\text { issuance }\end{array}$ & -.147 & .040 & -.402 & -3.641 & .001 \\
\hline $\begin{array}{l}\text { Income } \\
\text { level }\end{array}$ & .029 & .025 & .105 & 1.148 & .255 \\
\hline
\end{tabular}

\section{DISCUSSION}

After about ten years of the implementation of online payment method as one of the alternatives to pay assessment rate, the main concern of users seem to be the issuance of receipt. This was apparent in both correlation and multiple regression analysis test conducted. Furthermore, the questionnaire has provided an open ended question at the last section to invite respondents to give feedback on any related issues. Although a majority of the respondents chose not to give any feedback (65.7 per cent), 19.6 per cent mentioned the receipt issue. Respondents are more inclined on paying over the counter to get the receipt as proof of payment. Some have suggested that the local authority should come up with a mechanism that provides a proof of online payment, similar to a receipt issuance if paid via the counter. Other factors such as perceived usefulness, perceived ease of use and perceived risk have significantly correlated with user's intention to adopt online payment method, very much the same outcome with findings of other similar studies.

Previous studies affirmed that perceived usefulness is a significant factor in influencing electronic services adoption be it in the government or private sector alike and has contributed towards time and cost reduction (Akman et al., 2005; Bertot \& Jaeger, 2008; Evans \& Yen, 2006; Liao \& Cheung, 2002; Maniam \& Halimah, 2008; Ndou, 2004; Ooh et al., 2009; 
Poon, 2008; Ramlah et al., 2011). The survey found a significant percentage of online payment users among the respondents in MBSA. The result may be related to Shah Alam city status in which people in the city are perhaps more inclined to use online payment because it is perceived as useful in terms of time and cost saving especially in a demanding lifestyle. Payment over the counter requires users to come at specified time according to the operating hours, but with online payment, residents are able to pay at their convenience.

The findings of previous studies also found a significant relationship between perceived ease of use and the usage of online services especially in the public service delivery (Carter \& Belanger, 2005; He \& Mykytyn, 2007; Liao \& Cheung, 2002; Ooh et al., 2009; Poon, 2008; Ramlah et al, 2011). Users tend to be more inclined to use the eGovernment services when it is perceived as being conveniently accessible and easy to adopt. Perceived risk is found to be negatively influencing the intention to use the online payment method. This finding is consistent with results of previous studies that have shown perceived risk as an important determinant of e-Government services especially when it involves transactional services (Belanger \& Carter, 2008; Hung et al., 2006; Maizatul et al., 2011; Pavlou, 2003). Safety and security concerns often deter users from adopting the online payment method for fear of personal data abused and risk of account security breaches.

Out of the five factors identified as determinants for user's intention to use the online payment method, this study found that receipt issuance has the strongest correlation with user's adoption. Further, the multiple regression analysis confirms that receipt issuance is the strongest determinants among the five factors that affect user's intention to adopt the online payment method. To the best of the researchers' knowledge, no similar study has used receipt issuance as a construct to determine online payment adoption. However, this study accounted receipt issuance as a factor, postulating that the lower usage of online payment method in assessment rate collection has a relationship with the non-issuance of receipt when payment is made online. The findings proved that users are generally concern with the proof of payment when paying online. A majority of respondents (19.6 per cent) who answered the open ended question at the end of the questionnaire mentioned that the absence of receipt issuance discourage them to use the online payment method. 
Rustam Khairi Zahari, Raja Noriza Raja Ariffin, Nurhawani Zamin and Norzailawati binti Mohd Noor E-Payment at the Local Government Level: A Study of Majlis Bandaraya Shah Alam and Majlis Daerah Kampar

Income level may not be the strongest factor influencing the usage of online payment method but the hypothesis is still supported. Although some users may use internet facilities at the office or other places, having internet at home seems to be safer and less risky for them to make transaction that involves money and personal information. Therefore, it was hypothesized that income level positively influences user's intention to use the online payment method. The finding is consistent with previous study of Akhter (2003). Nevertheless, other studies have found no significant relationship between income level and online usage (He \& Mykytyn, 2007; Rhee \& Kim, 2004). In particular, Rhee and Kim (2004) acknowledge that income level is not significant because the internet facilities are widely made available for the public. In this regard, this study found that income level plays a role in influencing user's intention to adopt the online payment method. This is perhaps attributed to the user's ability to have internet facilities before enabling them to engage in online transactions.

It should also be noted that results of the study have shown important difference between user's preference mode of payment in MBSA and MDKpr, where MDKpr registered a lower percentage of online payment users. During the interview with MDKpr officers, it was informed that generally the public prefer to make payment over the counter, not necessarily for the receipt, but for the sake of meeting MDKpr staffs and perhaps some friends or familiar faces. This shows that although the local government has the capability of using e-payment, its traditional method of collection should be retained as certain segment of the community may prefer to use the 'over-the-counter' approach for any transactions. This was found to be true when some respondents did mention that they prefer to pay over the counter because they are satisfied with the good counter services. An effective collection of assessment rate is one of the most vital aspects for any local government as the revenue generated can significantly influenced the capability of the organisation in delivering its services to members of the public. As such it is imperative that the approached adopted in the assessment rate collection should be catered to the needs of the residents. 
PLANNING MALAYSIA

Urban Planning and Local Governance

\section{CONCLUSION}

This paper presents the findings of a study to investigate the factors influencing the usage of online payment method in local authority's assessment rate collection. Findings indicate that perceived usefulness, perceived ease of use, perceived risk, payment receipt issuance and income level has a significant relationship towards the intention to adopt the online payment method for paying assessment rate. Although there is generally positive perception from users to adopt the online payment method, there are some concerns that can be addressed in order to increase user's participation and to enhance the implementation of e-Services among the local government. In this context, the local authorities are encouraged to keep further strengthen the security of the online system; offer a wider selection of the online payment method and to provide proof of online payment. In a broader perspective, it is recommended that the government adopts the best practices of Republic of Korea's e-Government implementation that has seen impressive development throughout the years.

\section{REFERENCES}

Ainul Jaria Maidin and Bashiran Begum Mobarak Ali. (2009). Powers of the Local Authority in Regulating Land Planning and Development Control: Wither Control. Planning Malaysia - Journal of the Malaysian Institute of Planners VII, 133 - 147.

Ajzen, I. (1991). The Theory of Planned Behavior. Organizational Behavior and Human Decision Processes, 50, 179-211.

Akhter, S. (2003). Digital Divide and Purchase Intention: Why Demographic Psychology Matters. Journal of Economic Psychology, 24(3), 321-327.

Akman, I., Yacizi, A., Mishra, A., \& Arifoglu, A. (2005). E-Government: A global view and an empirical evaluation of some attributes of citizens. Government Information Quarterly, 22(2), 239-257.

Belanger, F., \& Carter, L. (2008). Trust and risk in e-government adoption. The Journal of Strategic Information Systems, 17(2), 165-176.

Bertot, J. C., \& Jaeger, P. T. (2006). User-centered e-government: Challenges and benefits for government Web sites. Government Information Quarterly, 23(2), 163-168.

Bertot, J. C., \& Jaeger, P. T. (2008). The E-Government paradox: Better customer service doesn't necessarily cost less. Government Information Quarterly, 25(2), 149-154. 
Rustam Khairi Zahari, Raja Noriza Raja Ariffin, Nurhawani Zamin and Norzailawati binti Mohd Noor E-Payment at the Local Government Level: A Study of Majlis Bandaraya Shah Alam and Majlis Daerah Kampar

Carter, L., \& Belanger, F. (2005). The utilization of e-government services: citizen trust, innovation and acceptance factors. Information Systems Journal, 15(1), 5-25.

Davis, F. D. (1989). Perceived Usefulness, Perceived Ease of Use, and User Acceptance of Information Technology. MIS Quarterly, 13(3), 319-340.

Eastin, M. S. (2002). Diffusion of e-commerce: an analysis of the adoption of four e-commerce activities. Telematics and Informatics, 19(3), 251-267.

Economic Planning Unit, Prime Minister's Department. (2006). Ninth Malaysia Plan: 2006-2010. Kuala Lumpur: Percetakan Nasional Malaysia Berhad.

Evans, D., \& Yen, D. C. (2006). E-Government: Evolving relationship of citizens and government, domestic, and international development. Government Information Quarterly, 23(2), 207-235.

Gupta, M. P., \& Jana, D. (2003). E-government evaluation: a framework and case study. Government Information Quarterly, 20(4), 365-387.

He, F., \& Mykytyn, P.P. (2007). Decision Factors for the Adoption of an Online Payment System by Customers. International Journal of E-Business Research, 3(4), 1-32.

Helbig, N., Gil-Garcia, J. R., \& Ferro, E. (2009). Understanding the complexity of electronic government: Implications from the digital divide literature. Government Information Quarterly, 26(1), 89-97.

Hung, S.-Y., Chang, C.-M., \& Yu, T.-J. (2006). Determinants of user acceptance of the e-Government services: The case of online tax filing and payment system. Government Information Quarterly, 23(1), 97122.

Lai, L. T., \& Rieck, O. (2005). Citizens as customers: Exploring the future of CRM in UK local government. Journal of Strategic Information Systems, 14(4), 417-440.

Liao, Z., \& Cheung, M. T. (2002). Internet-based e-banking and consumer attitudes: an empirical study. Information \& Management, 39(4), 283295.

Maizatul Haizan Mahbob, Mohammed Zin Nordin, Ali Salman, Wan Idros Wan Sulaiman, \& Mohd. Yusof Hj. Abdullah. (2011). Government to Citizen: Advocacy of Government On-line Systems and Their Acceptance among Citizens. The Innovation Journal: The Public Sector Innovation Journal, 16(3), 1-13.

Malaysian Administrative Modernisation and Management Planning Unit (MAMPU), Prime Minister's Department. (1997). Electronic Government Flagship Application: Blueprint for Electronic Government Implementation. Kuala Lumpur: Government of Malaysia. 
Maniam Kaliannan, \& Halimah Awang. (2008). Implementing Electronic Procurement in Government: A Case Study on e-Perolehan in Malaysia. Public Sector ICT Management Review, 2(1), 44-51.

Ndou, V. (2004). E-Government for developing countries: Opportunities and challenges. The Electronic Journal on Information Systems in Developing Countries, 18(1), 1-24.

Norhaslina Hassan, Noor Ismawati Mohd. Jaafar, Raja Noriza Raja Ariffin, Asmarulkhadi Abu Samag \& Mohd. Nazari Jaafar. (2013). Perceptions on Quality of Life in Malaysia: The Urban-Rural Divide. Planning Malaysia - Journal of the Malaysian Institute of Planners XI, 21-40.

Ooh, K.L., Suhaiza Zailani, T. Ramayah, \& Fernando, Y. (2009). Factors influencing intention to use e-government services among citizens in Malaysia. International Journal Of Information Management, 29(6), 458-475.

Pavlou, P. A. (2003). Consumer Acceptance of Electronic Commerce: Integrating Trust and Risk with the Technology Acceptance Model. International Journal of Electronic Commerce, 7(3), 69-103.

Poon, W.-C. (2008). Users' adoption of e-banking services: the Malaysian perspective. Journal of Business \& Industrial Marketing, 23(1), 59-69.

Ramlah Hussein, Nor Shahriza Abdul Karim, Norshidah Mohamed, \& Abdul Rahman Ahlan. (2007). The Influence of Organizational Factors on Information Systems Success in E-Government Agencies in Malaysia. The Electronic Journal on Information Systems in Developing Countries, 29(1), 1-17.

Ramlah Hussein, Norshidah Mohamed, Abd Rahman Ahlan, \& Murni Mahmud. (2011). E-government application: an integrated model on G2C adoption of online tax. Transforming Government: People, Process and Policy, 5(3), 225-248.

Reddick, C. G., \& Turner, M. (2012). Channel choice and public service delivery in Canada: Comparing e-government to traditional service delivery. Government Information Quarterly, 29(1), 1-11.

Rhee, K. Y. \& Kim, W.-B. (2004). The Adoption and Use of the Internet in South Korea. Journal of Computer-Mediated Communication, 9(4).

Rogers, E. M. (2003). Diffusion of Innovations $\left(5^{\text {th }}\right.$ Ed.). New York: Free Press.

Sandoval-Almazan, R., \& Gil-Garcia, J. R. (2012). Are government internet portals evolving towards more interaction, participation, and collaboration? Revisiting the rhetoric of e-government among municipalities. Government Information Quarterly, 29(s1), S72-S78.

Shareef, M. A., Kumar, V., Kumar, U., \& Dwivedi, Y. K. (2011). eGovernment Adoption Model (GAM): Differing service maturity levels. Government Information Quarterly, 28(1), 17-35. 
Rustam Khairi Zahari, Raja Noriza Raja Ariffin, Nurhawani Zamin and Norzailawati binti Mohd Noor E-Payment at the Local Government Level: A Study of Majlis Bandaraya Shah Alam and Majlis Daerah Kampar

Shyu, S.H-P., \& Huang, J-H. (2011). Elucidating usage of e-government learning: A perspective of the extended technology acceptance model. Government Information Quarterly, 28(4), 491-502.

Siddique, N.A. (2008). Service delivery innovations and governance: the Malaysian experience. Transforming Government: People, Process and Policy, 2(3), 194-213.

Sung-mi, K. (2012, March 8). South Korea's e-Government Development amazes the World in Winning UN e-Government Survey 2012. Korea IT Times. Retrieved from http://www.koreaittimes.com/

United Nations. (2003). UN Global E-Government Survey 2003. New York: United Nations.

United Nations. (2005). UN Global E-Government Readiness Report 2005: From E-Government to E-Inclusion. New York: United Nations.

United Nations. (2012). E-Government Survey 2012: E-Government for the People. New York: United Nations.

Venkatesh, V., Chan, F. K. Y., \& Thong, J. Y. L. (2012). Designing egovernment services: Key service attributes and citizens' preference structures. Journal of Operations Management, 30(1-2), 116-133.

Venkatesh, V., Morris, M. G., Davis, G. B., \& Davis, F. D. (2003). User Acceptance of Information Technology: Toward a Unified View. MIS Quarterly, 27(3), 425-478.

Yu, H.-C., Hsi, K.-H., \& Kuo, P.-J. (2002). Electronic payment systems: an analysis and comparison of types. Technology in Society, 24(3), 331347.

Yurita Yakimin Abdul Talib, Marlina Mohd Lazim, \& Mohamad Sharofi Ismail. (2005). A Study on the Computerized Revenue Collection System of Local Authority: A Case of Perlis, Kedah and Penang (UUM Working Paper No. 11/2005). Kedah: Universiti Utara Malaysia. 